\title{
D. João III e D. Miguel da Silva, bispo de Viseu: novas razões para um ódio velho
}

\author{
Ana Isabel Buescu \\ Dep. de História, FCSH-UNL \\ anabuescu@netcabo.pt \\ Texto recebido em/ Text submitted on: 10/02/2010 \\ Texto aprovado em/ Text approved on: 20/02/2010
}

\section{Resumo/Abstract:}

No Verão de 1540, D. Miguel da Silva (c. 1480-1556), escrivão da puridade de D. João III e bispo de Viseu, abandonou a cidade de Viseu, fugindo para Itália, de onde nunca regressou e onde veio a morrer em 1556. A versão fixada pela cronística e veiculada, quase ne varietur, pela historiografia, é de que a causa do ódio que D. João III veio a conceber por D. Miguel da Silva, a fuga deste para Itália e a perseguição que o monarca lhe moveu até à sua morte em Roma teria sido, em exclusivo e numa relação causal, a ascensão ao cardinalato, em 1539, à revelia da autoridade régia. Em nosso entender, este acontecimento deverá, antes, ser visto no âmbito de um conjunto complexo de razões em que o cardinalato tem, é certo, um papel de destaque, mas não exclusivo. Revisitar-se-á, pois, esta excepcional figura para avaliar e compreender, a uma nova luz, um dos mais perturbadores momentos do reinado de D. João III, que teve como protagonista D. Miguel da Silva, bispo de Viseu.

In the summer of 1540, D. Miguel da Silva (c. 1480-1556), secretary of king D. João III and bishop of Viseu, fled from the city of Viseu to Italy, where he remained for the rest of his life until he died in 1556. According to the chronicles and as narrated almost ne varietur by historiography, the cause of the hatred that king D. João III nurtured against D. Miguel da Silva, his escape to Italy and his persecution by the monarch until the year of his death in Rome was believed to have been, exclusively, his rise to Cardinal in 1539, against the King's will. It is our understanding that this event must rather be seen from the perspective of a complex set of motives, in which the cardinalate certainly plays an important, albeit not exclusive, part. Consequently, we will be revisiting this exceptional personality to attempt an assessment and understanding from a new perspective of one of the most disturbing episodes in the reign of D. João III, with D. Miguel da Silva, the Bishop of Viseu as its leading actor.

Palavras chave/Keywords:

D. Miguel da Silva; D. João III; Relações com a Santa Sé; Humanismo e Renascimento; Bispado de Viseu.

D. Miguel da Silva; D. João III; Relations with the Holy See; Humanism and Renaissance; Bishopric of Viseu. 
Por um amplo e multiforme conjunto de razões, D. Miguel da Silva, embaixador de D. Manuel I junto do Papa a partir de 1515, bispo de Viseu entre 1526 e 1547, e cardeal da Igreja de Roma desde 1539 até à sua morte, em 1556, perfila-se como uma das mais destacadas e singulares figuras da história portuguesa da primeira metade do século XVI. São conhecidos os traços mais marcantes do seu percurso de vida, em larga medida devido a um conjunto de estudos e de investigações que ajudaram a situar e a compreender uma figura que teve um papel de relevo na vida política, religiosa e diplomática portuguesas junto da Cúria romana, um contacto em muitos aspectos pioneiro - e privilegiado - com o mundo do humanismo italiano e as formas artísticas do Renascimento, e uma acção mecenática invulgar, nomeadamente enquanto bispo de Viseu ${ }^{1}$.

1 Indicam-se os mais relevantes estudos sobre a figura de D. Miguel da Silva; muitas outras referências, entre fontes narrativas e documentais e estudos irão sendo citadas ao longo deste texto. HERCULANO, Alexandre - História da Origem e Estabelecimento da Inquisição em Portugal, revisão de Vitorino Nemésio, introdução de Jorge Borges de Macedo, II. Lisboa: Bertrand, 1981 ( $1^{\text {a }}$ ed. 1854-59), p. 267-299. ALMEIDA, Fortunato de - História da Igreja em Portugal, nova edição preparada e dirigida por Damião Peres, II. Porto-Lisboa: Livraria Civilização Editora, 1968 (1 $1^{\mathrm{a}}$ ed. 1910-28), p. 659-669. CASTRO, José de - Dom Miguel da Silva: o "Cardeal de Viseu". Beira Alta, IV, fasc. IV (4º trimestre), (1945) e V, fasc. 1 ( $1^{\circ}$ trimestre) (1946) (http://visoeu.blogspot.com/2005/04/dom-miguel-da-silva-o-cardeal-de-viseu.html e http://visoeu.blogspot.com/2005/04/dom-miguel-da-silva-o-cardeal-de-viseu-22.html consultados em 2008.02.20). DIAS, José Sebastião da Silva - A Política Cultural da Época de D. João III, I. Coimbra: Universidade de Coimbra, 1969, p. 76-106. MOREIRA, Rafael - D. Miguel da Silva e as origens da arquitectura do Renascimento em Portugal. O Mundo da Arte. Revista de Arte, Arqueologia e Etnografia, II série, I, Lisboa: 1988, p. 5-23 [em que se retoma o texto de uma comunicação de 1983]. DESWARTE, Sylvie - Il Perfetto Cortegiano. D. Miguel da Silva. Roma: Bulzoni Editore, 1989. COUTO, Aires Pereira do - O grande 'senhor' do Fontelo do século XVI: D. Miguel da Silva Beira Alta, XLIX, fasc. 3 e 4 ( $3^{\circ}$ e $4^{\circ}$ trimestres, 1990) ( http://visoeu.bolgspot.com/2005/11/quinta-do-fontelo-obra-de-d-miguel-da.html consultado em 2009.10.22). MOREIRA, Rafael O primeiro mecenas: D. Miguel da Silva e a arquitectura no Norte. História da Arte Portuguesa, dir. PEREIRA, Paulo, II - Do 'Modo' Gótico ao Maneirismo, Lisboa: Círculo de Leitores, 1995, p. 332-339. Não nos foi possível consultar a obra de ALMEIDA, Adelaide Vaz de - D. Miguel da Silva, séc. XV-XVI. Lisboa: ed. Autor, 2001, originalmente tese de licenciatura em Ciências Histórico-Filosóficas apresentada em 1948 à Faculdade de Letras da Universidade de Coimbra com o título O Bispo-Embaixador Dom Miguel da Silva. Agradecemos à $\mathrm{Sr}^{\mathrm{a}} \mathrm{D}$. Lourdes Reis, da Biblioteca da FCSH, os esforços para localizar um exemplar da edição de 2001 . 
Permanecem, contudo, zonas de sombra, relativamente a questões cruciais dadas como resolvidas em termos da interpretação histórica, na vida e nas acções do bispo de Viseu, facto que clama uma urgente revisão, como foi recentemente notado ${ }^{2}$. Como essas questões - no ponto que iremos aqui explorar - envolvem também o rei D. João III e a própria coroa, podemos sem risco de extrapolação abusiva afirmar que dizem respeito ao âmago da história portuguesa do século XVI. Revisitar-se-á, pois, esta excepcional figura para avaliar e compreender, a uma nova luz, um dos mais perturbadores momentos do reinado de D. João III que teve como protagonista o bispo de Viseu: a sua fuga do reino, no Verão de 1540, para Itália, de onde nunca regressou e onde veio a morrer, cardeal, em 1556, mas desde 1542 "condenado sem processo à morte civil" pelo monarca 3 .

Recordemos alguns factos relevantes da sua vida. D. Miguel da Silva nasceu c. 1480, em Évora, no seio de uma linhagem antiga, em ascensão desde o século XIV ${ }^{4}$. Era filho de D. Diogo da Silva de Meneses 5 , futuro $1^{\mathrm{o}}$ conde de Portalegre, e de D. Maria de Ayala ${ }^{6}$. Pertencia, por nascimento, a uma família da mais alta aristocracia do reino. Se podemos imaginar, a partir da sua condição social, o que terá sido a sua infância, certamente idêntica, nos quotidianos, nas aprendizagens e nas práticas, à de outras crianças nobres, a antiga e reiterada proximidade da sua linhagem à coroa havia de, também no seu caso, repercutir-se no seu destino pessoal.

2 PAIVA, José Pedro - Os Bispos de Portugal e do Império 1495-1777. Coimbra: Imprensa da Universidade, 2006, p. 210, n. 150. Agradecemos ao nosso Colega da Faculdade de Letras da Universidade de Coimbra a atentíssima leitura deste texto, bem como as sugestões feitas, que permitiram aperfeiçoá-lo na sua forma final.

3 HERCULANO, Alexandre - História da Origem ..., cit., II, p. 293.

4 Sobre as origens da linhagem, v. FREIRE, Anselmo Braamcamp - Brasões da Sala de Sintra, $2^{\mathrm{a}}$ ed., II. Lisboa: IN-CM, 1973, p. 3-21.

5 Terceiro filho de Rui Gomes da Silva, alcaide-mor de Campo Maior e Ouguela, cavaleiro da casa do infante D. Duarte e conselheiro de D. Afonso V, e de D. Isabel de Meneses, filha bastarda de D. Pedro de Meneses, $1^{\circ}$ capitão de Ceuta e $1^{\circ}$ conde de Vila Real. FREIRE, Anselmo Braamcamp - Brasões...,. II, cit., p. 22-24.

6 Filha de D. Diego de Ayala e de Inês de Peraça, e neta do senhor das ilhas Canárias, onde Diogo da Silva de Meneses, então ligado à casa do infante D. Fernando, serviu durante cerca de três anos. SILVÉRIO, Silvina e MARQUES, Marisa Pires - Diogo da Silva de Meneses e a política régia ultramarina. COSTA, João Paulo Oliveira e RODRIGUES, Vítor Luís Gaspar (ed.) - A Alta Nobreza e a Fundação do Estado da Índia. Colóquio Internacional. Actas. Lisboa: UNL/CHAM, IICT/CEHCA, 2004, p. 244. 
$\mathrm{O}$ valimento de seu pai junto de D. Afonso $\mathrm{V}$ e de D. João II, feito de acções militares, em África e Castela, serviço e fidelidade política, foi inegável, materializando-se em subidas mercês, património e prestígio; mas foi a sua relação com o duque de Beja, D. Manuel, de quem foi "aio e governador" por determinação de D. João II que cimentou, em definitivo, a ascensão da sua casa. Na verdade, se, ainda enquanto duque, D. Manuel cumulou de mercês o seu aio e vedor da fazenda, com quem mantinha uma relação de profundo afecto e confiança, após subir ao trono, além de confirmar todas as mercês concedidas pelos seus predecessores, o rei não tardou em distinguir D. Diogo da Silva de Meneses, logo em 1496, com o título de conde de Portalegre, de juro e herdade, para si e seus herdeiros, embora a outorga definitiva do título datasse de $1498^{8}$.

Teve D. Diogo da Silva de Meneses, do seu casamento com D. Maria de Ayala, dois filhos varões, e duas filhas, Inês e Joana. As estratégias matrimoniais concebidas para os seus descendentes evidenciam o desejo de engrandecimento e afirmação da sua linhagem. Inês veio a casar com D. Pedro de Castro, $3^{\circ}$ conde de Monsanto ${ }^{9}$, e Joana com D. António de Noronha, irmão do marquês de Vila Real, primo de D. Manuel e futuro $1^{\circ}$ conde de Linhares, em 1502. Eram parentes, pois todos quatro descendiam, elas por via bastarda e feminina, do grande capitão de Ceuta e $1^{\circ}$ conde de Vila Real, D. Pedro de Meneses ${ }^{10}$. O mais velho dos filhos varões, João, a quem cabia herdar o título condal, consorciou-se em 1505, já após a morte do pai, ocorrida no ano anterior, com D. Maria de Meneses, irmã do $1^{\circ}$ conde de Tentúgal ${ }^{11}$, D. Rodrigo de Melo, sobrinho de D. Manuel.

7 Como é nomeado no regimento dado a D. Diogo da Silva por D. João II numa das suas idas a Castela. SALGADO, Anastásia Mestrinho e SALGADO, Abílio José (ed.) - Álvaro Lopes de Chaves. Livro de Apontamentos (1438-1489). Códice 443 da Colecção Pombalina da BNL. Lisboa: IN-CM, 1984, p. 157.

8 FREIRE, Anselmo Braamcamp - Brasões..., cit., pp. 23-24. SILVÉRIO, Silvina e MARQUES, Marisa Pires - Diogo de Silva de Meneses..., cit., p. 249.

9 Tratou-se do segundo casamento de D. Pedro de Castro. FREIRE, Anselmo Braamcamp - Brasões..., cit., p. 25.

${ }^{10}$ V. supra, notas 4 e 5 e genealogias 2, 3 e 5 em TEIXEIRA, André Pinto de Sousa Dias - Uma linhagem ao serviço da 'ideia imperial manuelina': Noronhas e Meneses de Vila Real, em Marrocos e na Índia. COSTA, João Paulo Oliveira e RODRIGUES, Vítor Luís Gaspar (ed.) - A Alta Nobreza... cit.

${ }^{11}$ Título criado por D. Manuel em 1504. FREIRE, José Braamcamp - Brasões...vol. III, cit., p. 367-368. 
Para o filho varão mais novo de D. Diogo, Miguel, como então sucedia com os secundogénitos das grandes casas, as possibilidades que se desenhavam, num quadro de proximidade com a corte régia e de favor junto de D. Manuel eram as armas, o alto serviço do rei, uma possível carreira eclesiástica, talvez especialmente valorizada numa família em que a veemência da devoção franciscana - que D. Diogo terá transmitido a D. Manuel ${ }^{12}$ - produzira dois santos: Beatriz da Silva ${ }^{13}$, fundadora da ordem das religiosas da Conceição de Maria, em Toledo, de monjas contemplativas e seguidoras de uma versão rigorista da regra de S. Francisco, que veio a ser canonizada, e o beato e místico frei Amadeu, no século João da Silva, que viveu como eremita em Itália, onde fundou vários pequenos conventos de "espirituais" de estrita observância franciscana ${ }^{14}$. Eram ambos irmãos de D. Diogo, pelo que D. Miguel da Silva era sobrinho carnal de duas personalidades tocadas pela santidade, facto que também neste, como noutros casos no seio da aristocracia, constituía um capital simbólico e de prestígio incorporado, como os feitos de armas ou de honra, no património da memória familiar e da linhagem.

Revelou Miguel da Silva, desde cedo, singulares dotes intelectuais; por isso, depois de uma aprendizagem comum aos filhos da aristocracia, enveredou pelos estudos universitários. Após os primeiros estudos na Universidade de Lisboa, D. Manuel I julgou por bem enviá-lo para a Universidade de Paris onde, entre 1500 e 1513, com estadia também em Siena, completou a sua formação em teologia e humanidades. Nessa estadia por terras de França e Itália adquiriu uma sólida cultura e um profundo conhecimento

12 THOMAZ, Luís Filipe - L'idée impériale manuéline. La Découverte, le Portugal et l'Europe. Actes du Colloque (Paris, 26-28 mai 1988). Paris: FCG/CCP, 1990, espec. p. 83-86. Sobre o papel de Duarte Galvão na configuração da ideia messiânica em torno de D. Manuel, v. AUBIN, Jean - Duarte Galvão. Le Latin et l'Astrolabe. Recherches sur le Portugal de la Renaissance, son expansion en Asie et les relations internationales. vol. 1. Lisbonne-Paris: CCCG/CNCDP, 1996, p. 11-48. E sobre a expressão arquitectónica, iconográfica e simbólica da razão imperial manuelina, v. os estudos de PEREIRA, Paulo - A simbólica manuelina. Razão, celebração, segredo. História da Arte Portuguesa, dir. PEREIRA, Paulo, II Do 'Modo' Gótico ao Maneirismo. Lisboa: Círculo de Leitores, 1995, p. 115-155.

${ }^{13}$ Dama de D. Isabel (1428-96), filha do infante D. João († 1442), mestre da Ordem de Santiago e neta de D. João I, que casou em 1447 com Juan II de Castela. Foi mãe da futura Isabel a Católica.

${ }^{14}$ FREIRE, Anselmo Braamcamp - Brasões..., II, cit., p. 20. THOMAZ, Luís Filipe L'idée impériale..., cit., p. 84. 
das línguas clássicas ${ }^{15}$, várias vezes invocado quer por figuras ligadas ao estreito círculo dos humanistas portugueses, como João Rodrigues de Sá de Meneses ou André de Resende, quer por filólogos e humanistas italianos, como Lattanzio Tomei ou Gregorio Giraldi ${ }^{16}$.

Concluída a sua formação, e como seria a muitos títulos expectável, D. Miguel da Silva, sem nunca ter voltado a Portugal ${ }^{17}$, recebeu de D. Manuel um cargo de grande importância e distinção. Nomeou-o o monarca seu embaixador junto da Cúria romana, em substituição do doutor João Faria, que mandou regressar ao reino por carta de 30 de Agosto de $1514^{18}$. D. Miguel da Silva tornou-se o segundo representante permanente do rei de Portugal junto do papado, numa conjuntura de irradiação europeia do poder e do prestígio da realeza manuelina, de que a entrada triunfal de Tristão da Cunha em Roma, em embaixada enviada pelo monarca ao Papa Leão X, precisamente nesse ano de 1514 , foi o mais eloquente testemunho ${ }^{19}$.

Iniciando formalmente a sua embaixada nos começos do ano de $1515^{20}$, D. Miguel da Silva viu-se encarregado pelo rei de duas tarefas de relevo: a de assistir ao V Concílio de Latrão (1512-17), e a de solicitar ao Papa Leão X o estabelecimento da Inquisição em Portugal, em idênticas condições com que fora concedida aos reinos de Castela e Aragão em $1478^{21}$. A primeira carta dirigida ao rei D. Manuel, no uso oficial das suas funções, data de

${ }^{15}$ Além do domínio do francês e da língua toscana. Em carta enviada a D. Manuel, D. Miguel da Silva dizia ao monarca que falava dos negócios do reino com o papa, então Leão X, em língua toscana - e não em latim. ANTT, CC, P. I, mç 20, doc. 123, de 11 de Novembro de 1516.

${ }^{16}$ DIAS, José Sebastião da Silva - A Política Cultural..., cit., p. 76-77.

${ }^{17}$ É essa a convicção, documentalmente sustentada, de DIAS, José Sebastião da Silva A Política Cultural..., cit., p. 78-79.

${ }^{18}$ Corpo Diplomático Portuguez (= CDP), publ. por SILVA, Luís Augusto Rebelo da, Lisboa: Academia Real das Ciências, T. I, 1862, p. 267, cit. por DIAS, José Sebastião da Silva - A Política Cultural ..., cit, p. 77, nota 3.

${ }^{19}$ GÓIS, Damião de - Crónica do Felicissimo Rei D. Manuel, nova edição conforme a primeira de 1566. Coimbra: Universidade de Coimbra, III, 1954, caps. 55-57. V. ainda COSTA, João Paulo Oliveira e - D. Manuel I. 1469-1521. Um Príncipe do Renascimento. Lisboa: Círculo de Leitores, 2005, p. 164-165.

${ }^{20}$ DESWARTE, Sylvie - Il Perfetto Cortegiano..., cit., p. 177-178, nota 19.

${ }^{21}$ As Gavetas da Torre do Tombo, Lisboa: CEHU, vol. 1, 1960, p. 60-63. DIAS, José Sebastião da Silva - A Política Cultural..., cit., p. 77-78. 
31 de Março de $1515^{22}$. Era o início de uma actividade diplomática intensa numa Roma que, no século XVI, se erigia como o maior e mais importante centro de informações e de circulação de notícias em toda a Cristandade. E o contexto era o de afirmação - e de "afinação" - dos mecanismos diplomáticos como instrumento de acção política, com destaque para a generalização da figura do embaixador permanente e a utilização cada vez mais frequente da cifra na correspondência diplomática. Não deixa de ser significativo observar essas duas realidades através da embaixada de D. Miguel da Silva: segundo representante permanente da coroa portuguesa junto da Santa Sé, foi com a sua embaixada que teve início o uso da cifra na correspondência diplomática portuguesa, sendo que a primeira carta da chancelaria que a utiliza foi uma missiva que endereçou a D. Manuel, datada de 11 de Novembro de $1516^{23}$.

Os dez anos (1515-25) durante os quais D. Miguel da Silva permaneceu como embaixador português na Cúria foram anos decisivos, do ponto de vista das dinâmicas internas do reino, dos caminhos da construção do império e de uma interacção cada vez mais intensa com as realidades políticas de uma Europa agitada por profundas transformações. A afirmação de uma Espanha politicamente unificada e, a partir de 1519, ligada aos destinos do Sacro Império Romano-Germânico, era uma nova realidade que teria de repercutir-se nos equilíbrios europeus, desenhando uma nova correlação de forças entre a França e a Espanha, potências que disputaram a hegemonia europeia na primeira metade do século XVI ${ }^{24}$. A história da Europa é indissociável deste conflito, que condicionou também a política e a diplomacia papais, ao tempo da embaixada de D. Miguel da Silva, condicionando alinhamentos e alianças, solidariedades e interesses.

${ }^{22}$ ALMEIDA, Fortunato de - História da Igreja..., II, cit., p. 661. ANTT, CC, P. I, mç. 17, doc. 108 .

${ }^{23}$ CRUZ, Maria Augusta Lima e LÁZARO, António Manuel - A linguagem criptográfica na correspondência diplomática portuguesa de D. Miguel da Silva e de Pêro Correia: origens e significado, in CARNEIRO, Roberto e MATOS, Artur Teodoro de (coord.) - D. João III e o Império. Actas do Congresso Internacional Comemorativo do seu Nascimento (Lisboa e Tomar, 4 a 8 de Junho de 2002). Lisboa: CHAM/CEPCEP, 2004, p. 601-620. Inclui a publicação da carta em questão.

${ }^{24}$ RICE, Eugene e GRAFTON, Anthony - The Foundations of Early Modern Europe, 1460-1559. Nova Iorque, Londres: W.W. Norton \& Company, 1994, p. 110-145. SALLMANN, Jean-Michel - Nouvelle Histoire des Relations Internationales, 1 - Géopolitique du xvie siècle 1490-1618. Paris: Seuil, 2003, p. 211-237. 
Mas, por esses anos, era também o rosto religioso da Europa que mudava sendo que, numa época em que política e religião se encontravam profundamente imbricadas, tal facto não podia deixar de ter implicações que ultrapassavam, em muito, a esfera da estrita espiritualidade. A 3 de Janeiro de 1521, o papa Leão X (1513-21), através da bula Decet Romanum Pontificem excomungava e expulsava Martinho Lutero (1483-1546) e os seus partidários da Igreja. Era o culminar de um processo que se iniciara anos antes, quando, em 31 de Outubro de 1517, o monge agostinho dava simbolicamente início à Reforma religiosa na Europa, ao afixar as 95 Teses Contra as Indulgências na porta da igreja do castelo de Wittenberg. Poucos dias depois da excomunhão de Lutero, Carlos V, recém-eleito imperador do Sacro Império Romano-Germânico, convocava a Dieta imperial para a cidade de Worms, onde Lutero recusou retractar-se. Um mês, o édito de Worms declarava-o fora-da-lei e bania-o do Império. A Reforma estava em marcha, e a cisão religiosa da Cristandade era uma realidade sem retorno ${ }^{25}$. Era, também, uma situação nova, com que, para além dos aspectos confessionais, eclesiais e sociais, em breve também militares, a política e a diplomacia europeias doravante se confrontavam.

Dividida pela fé e pela disputa da hegemonia política entre as duas mais poderosas monarquias em palco italiano, a Europa do século XVI confrontou-se também com o poder dos Turcos Otomanos. A conquista de Constantinopla em 1453, depois de uma progressão contínua desde o século XIV da Ásia para Ocidente, foi decisiva para a consolidação do Império Otomano. Para além do golpe simbólico, os Cristãos perderam a única base estratégica contra os Turcos, que conseguiam não apenas um retumbante triunfo militar, mas ganhavam uma nova capital para um império que se estendia pela Europa e pela Ásia, em breve também em África. Em Outubro de 1520 Carlos V era coroado imperador do Sacro Império Romano-Germânico em Aix-la-Chapelle; precisamente um mês antes, Soleimão sucedia no trono da "Sublime Porta" a seu pai Selim I $(† 1520)$. Dois destinos que protagonizaram um confronto sem tréguas entre

${ }^{25}$ CHAUNU, Pierre - Le Temps des Réformes. Histoire Religieuse et Système de Civilisation, I - La Crise de la Chrétienté 1250-1550. II - La Réforme Protestante. Paris : Editions Complexe, 1984; DELUMEAU, Jean - A Civilização do Renascimento, 2 vols. Lisboa: Estampa, 1984. 
dois impérios, dois homens, mas também, pelo peso simbólico, cultural e religioso que envolvia, entre a Cristandade e o Islão.

Soleimão vivera parte substancial da sua vida em Constantinopla e conhecia bem a situação política europeia, marcada pela Reforma religiosa e pela luta entre Carlos V e Francisco I, na qual viria, aliás, a interferir de forma activa. Em 1521, Soleimão tomou Belgrado e, em Dezembro de 1522 , os turcos apoderavam-se da ilha de Rodes expulsando os cavaleiros hospitalários de S. João e consolidando o seu poderio no Mediterrâneo oriental. O seu plano de expansão pelo continente, que sofreu o primeiro revés em 1529, no cerco à cidade de Viena teria, em 1571, já sob o consulado de Soleimão II, o seu ocaso na Batalha de Lepanto, que susteve essa até então quase contínua progressão do Império Otomano rumo ao Ocidente ${ }^{26}$. Portanto, no que respeita à cronologia em causa (1515-25), esta foi também uma das realidades políticas que condicionaram a história europeia ${ }^{27}$.

Regressemos a Roma e a D. Miguel da Silva, a um tempo espectador atento e participante deste xadrez complexo, matérias, todas elas, e muitas outras ainda, de maior minudência, delicadeza ou secretismo, sobre as quais lhe cabia manter o seu soberano informado e agir de acordo com as suas instruções. Para D. Miguel da Silva, embaixador na Cúria pontifícia de um rei opulento como era D. Manuel I, e a partir de Dezembro de 1521 de D. João III, oriundo da mais alta nobreza do reino e movimentando-se com inteligência nos meandros e nos bastidores da diplomacia e da política, mas também nos círculos da cultura artística e intelectual da Roma do seu tempo, genuinamente apreciado por papas e artistas, pintores e poetas, esta foi a década que dele fez, para a posteridade, o modelo do perfeito cortesão ${ }^{28}$.

${ }^{26}$ Privilegiamos aqui o confronto entre a Europa e a "Sublime Porta", o que não significa que não consideremos outras componentes de uma relação longa e complexa, em que as dimensões económica, diplomática e cultural têm um peso que a mais recente historiografia tem procurado destacar e aprofundar. V. Les Turcs, des Ottomans à l'Europe, Les Collections de L'Histoire, 45 (2009).

${ }^{27}$ Sobre o Império Otomano, v. QUATAERT, Donald - O Império Otomano. Das Origens ao século $X X$, Lisboa: Edições 70, 2008, p. 13-58. Continua a ser útil a obra de COLES, Paul - Os Turcos na Europa, Lisboa: Verbo, s/d.

${ }^{28}$ DESWARTE, Sylvie - Il Perfetto Cortegiano..., cit.. 
Em particular, o favor dos papas ${ }^{29}$ que se sucederam no sólio pontifício enquanto durou a sua embaixada - Leão X (1513-21), Adriano VI (1522-23) e sobretudo Clemente VII (1523-34), com quem mantinha uma amizade anterior à sua eleição como papa, e depois Paulo III (1534-49) e Júlio III (1549-55) - foi inequívoco e constante, pontuado por manifestações de apreço por D. Miguel, que haviam de culminar, em 1539, com a concessão do cardinalato. Já antes, em $1516^{30}$, e depois em 1521, Leão X encarara a hipótese de lhe conceder a púrpura ${ }^{31}$, o que acabou por não acontecer, porventura em virtude da morte do pontífice, num processo que causou comoção na corte portuguesa. O favor de D. Miguel da Silva junto do papado e da cúria significou um claro alinhamento com a política pontifícia, em particular no que respeita ao continuado conflito que opunha Carlos V e Francisco I, mas também às tensões entre o imperador e o papa, de que o saque de Roma pelas tropas imperiais, em 1527, e o aprisionamento de Clemente VII no castelo de Sant'Angelo foram acontecimentos que ecoaram por toda a Cristandade.

Mas D. Miguel da Silva foi também um agente em quem, tanto quanto nos é possível avaliar, D. Manuel I depositou uma total confiança, encarregando-o de inúmeras e sensíveis matérias e questões que D. Miguel tratou aparentemente sempre a contento ${ }^{32}$ de um rei que o havia feito e mantido seu embaixador no lugar mais poderoso de toda a Cristandade, lugar de topo - e de consagração - de qualquer carreira diplomática, como

${ }^{29}$ É conveniente recordar que quer Leão X quer Clemente VII eram Médici, e Paulo III Farnese, ambas famílias com as quais D. Miguel da Silva manteve laços estreitos desde o início da sua estadia italiana. Adriano VI, o austero flamengo Adrian Florenz (Utrecht), ex-preceptor de Carlos V, foi regente de Castela no conturbado período da revolta das Comunidades (1520-22), quando Carlos abandonou a Espanha para recolher a coroa imperial.

${ }^{30}$ Distinção que D. Miguel terá declinado. CASTRO, José de - Dom Miguel da Silva: o 'Cardeal de Viseu', cit. p. 2, o que, a ser verdade, poderá ligar-se à concessão do cardinalato ao infante D. Afonso, em 1517, depois de difícil processo desencadeado por D. Manuel em 1512. D. Miguel da Silva informava o monarca da eleição de D. Afonso por carta de 15 de Julho de 1517. ANTT, CC, P. I, mç. 22, doc. 32. ALMEIDA, Fortunato de - História da Igreja ..., cit., II, p. 52-53 e p. 580. PAIVA, José Pedro - Um príncipe na diocese de Évora: o governo episcopal do cardeal D. Afonso (1523-1540). Revista de História da Sociedade e da Cultura, 7 (2007), 138-139. Neste contexto, seria problemático D. Miguel da Silva corresponder à intenção papal.

${ }^{31}$ DIAS, José Sebastião da Silva - A Politica Cultural..., cit., p. 86 e nota 5.

${ }^{32}$ PAIVA, José Pedro - Os Bispos..., cit., p. 305. 
poderíamos dizer numa perspectiva contemporânea. A 13 de Dezembro de 1521, numa Lisboa tomada pelos ares da pestilência, D. Manuel I morreu, subindo ao trono D. João $\mathrm{III}^{33}$. O reinado do jovem monarca iniciava-se sob o signo de uma certa continuidade governativa, o que não significa que não houvesse lugar a inflexões várias e percursos ascensionais e de empalidecimento junto do novo soberano, mais ou menos notórios e, em particular no interior da nobreza, a verdadeiros “ajustes de contas" em que tomou parte activa o próprio rei ${ }^{34}$. Como em vários outros cargos e lugares de preeminência, no que respeita à embaixada na cúria romana D. João III pareceu optar pela continuidade, mantendo D. Miguel da Silva como seu embaixador, e encarregando-o, a breve trecho, de uma negociação sensível. Dando sequência à política manuelina de privilegiar, nos grandes cargos eclesiásticos, os membros da família real ${ }^{35}$, logo em 1522 o monarca procurou nomear o seu irmão o infante D. Henrique para o bispado de Viseu. Sem sucesso, pois o papa Adriano VI opôs-se terminantemente a tal nomeação, apesar da insistência régia e das diligências do seu embaixador ${ }^{36}$.

Algo mudava, no entanto, mas de forma subtil, como era apanágio de D. João III. O mal-estar do diplomata começou com a morte de D. Manuel I, lastimando-se D. Miguel reiteradamente, na correspondência enviada, da falta de instruções por parte do novo monarca ${ }^{37}$. Em Maio de 1523, ainda durante o breve e estrito pontificado de Adriano VI, D. Miguel da Silva escrevia a D. João III exprimindo-lhe o desejo de voltar ao reino, carta que o monarca guardou ciosamente ${ }^{38}$, embora em Novembro desse mesmo ano a eleição do seu particular amigo Giulio de Médici como papa o tenha feito voltar atrás nessa intenção; de forma um pouco ostensiva, informava o rei de que assistiria à cerimónia de entronização de uma janela do conclave, honra

${ }^{33}$ Sobre a doença e morte de D. Manuel, v. GÓIS, Damião de - Crónica do Felicíssimo Rei D. Manuel, cit., IV, 1955, cap. 83. BUESCU, Ana Isabel - D. João III (1502-1557). Lisboa: Temas \& Debates, 2008, p. 115-120.

${ }^{34}$ AUBIN, Jean - La noblesse titrée sous D. João III: inflation ou fermeture?, in Le Latin et l'Astrolabe ..., cit., I, 1996, p. 371-383. BUESCU, Ana Isabel - D. João III, cit., p. 147-153.

${ }^{35}$ PAIVA, José Pedro, Os Bispos..., cit., p. 298-299, retomado em IDEM, Um príncipe na diocese de Évora, cit., p. 137-138.

${ }^{36}$ PAIVA, José Pedro - Os Bispos..., cit., p. 50.

${ }^{37}$ DIAS, José Sebastião da Silva - A Política Cultural ..., cit., p. 97-98.

${ }^{38}$ ANTT, P. I, mç. 29, doc. 68, de 25 de Maio de 1523. V. CASTRO, José de - Dom Miguel da Silva: o 'Cardeal de Viseu', cit., p. 2. 
que mais nenhum embaixador alcançara ${ }^{39}$. Entretanto, no âmbito do processo que levou, em 1524, ao contrato de casamento de D. João III com Catarina de Áustria, foi D. Miguel da Silva quem tratou das dispensas na cúria. Data talvez dessa altura a entrada do embaixador português no Conselho régio ${ }^{40}$.

No início de Agosto de 1525, ano em tantos aspectos crucial dos primeiros tempos da governação de D. João III - o seu casamento com D. Catarina, as primeiras cortes do reinado, em Torres Novas, as negociações do casamento da infanta D. Isabel com Carlos V, o primeiro pedido de estabelecimento da Inquisição no reino - D. Miguel da Silva regressou a Portugal. Fê-lo por expressa ordem de D. João III mas com inequívoca relutância, depois de uma ausência contínua de vinte e cinco anos. Este facto é importante para entender os contextos do seu regresso ao reino, quer do ponto de vista do próprio, do ambiente que o recebeu e do meio em que veio a inserir-se.

Embora, pela sua própria condição de embaixador, a relação com Portugal permanecesse parte integrante da sua identidade, com cerca de quarenta e cinco anos de idade e depois de vinte e cinco anos de ausência, D. Miguel da Silva era, verdadeiramente, um estrangeirado - e outro o país a que voltava. Como havia de suceder, anos mais tarde, com Damião de Góis, na estreiteza de uma corte menos cosmopolita do que por vezes se supõe, a aparência, os gostos, os projectos, as estátuas, os livros e os manuscritos que trouxe, a altivez aristocrática de quem habitara Roma, privara com papas e cardeais, conhecera Tiziano e Miguel Ângelo, proporcionaram, a breve trecho, um clima hostil e de intriga contra o "romano" D. Miguel"1. Depois, sob o estrito ponto de vista político, D. Miguel surgia como um fiel servidor da Santa Sé, e um homem também ele com um profundo conhecimento e acesso a papéis e segredos de Estado, facto que concitou a reserva e a surda hostilidade dos poderosos Alcáçova Carneiro ${ }^{42}$. Acresce ainda que o

${ }^{39}$ ANTT, P. I., mç. 30, doc. 61.

40 "eu sprevo a Dom Miguel da Sylva, do meu Conselho e meu embaixador, que falle a Vosa Santidade algummas cousas tocantes a meu casamento com a $\mathrm{Ilm}^{a}$ e muy excelemte primcesa Ifamta Dona Caterina". Cit. por DIAS, José Sebastião da Silva - A Política Cultural..., cit., p. 79, nota 4. Publ., sem indicação de data, no CDP, II, p. 216.

${ }^{41}$ Rafael Moreira anota "o seu feitio amante da ostentação e arrogante". MOREIRA, Rafael - D. Miguel da Silva e as origens da arquitectura..., cit., p. 8.

${ }^{42}$ Como sublinha Herculano. História da Origem ..., cit., II, p. 269-270. António Carneiro, que já servira D. João II como escrivão da câmara, foi escolhido por D. Manuel I para seu 
seu regresso acarretou a concessão de cargos e distinções que provocaram resistências e intriga na corte, com destaque para o dissídio com o cunhado, D. António de Noronha, que perdeu para D. Miguel da Silva o cargo de escrivão da puridade. Finalmente, vinte e cinco anos passados, o panorama humano mudara; muitos rostos e figuras que D. Miguel conhecera na sua juventude tinham já desaparecido. Não conhecia sequer pessoalmente o monarca que agora servia, nascido já depois da sua partida para Paris.

Vejamos este aspecto, já que se reveste de importância para iluminar, embora conjecturalmente - mas, pensamos, com verosimilhança -, alguns dos contornos da fuga de D. Miguel da Silva, no ainda longínquo Verão de 1540. Embora não saibamos, de forma positiva, qual a relação entre ele e D. João III à época do seu regresso ao reino, os indícios parecem apontar para uma reserva, de contornos difusos embora, por parte do rei. Ao contrário do que dominantemente se escreveu, nada nos permite sustentar a existência de uma relação cordial ou, pelo menos, politicamente "inócua", se assim pode dizer-se, entre D. Miguel e D. João III, que só se teria quebrado, e de forma fulminante, com a concessão do cardinalato em 1539 pelo papa Paulo III. A versão fixada pela cronística ${ }^{43}$ e veiculada, quase ne varietur, pela historiografia, é de que a causa directa do ódio que D. João III viria a conceber por D. Miguel da Silva, a fuga deste para Itália e a perseguição tenaz que o monarca lhe moveu até à sua morte em Roma teria sido, em exclusivo e numa relação causal, a ascensão ao cardinalato, à revelia da autoridade régia ${ }^{44}$. Não nos parece que assim seja.

secretário em 1509, dando início ao protagonismo de uma família de altos funcionários régios que teve em Pedro de Alcáçova Carneiro (1515-93) o seu mais destacado membro, cuja presença no aparelho administrativo e político do reino se prolongou após 1580 . Por alvará de 1582 e carta régia de 1584, Filipe I fê-lo conde da Idanha. BUESCU, Ana Isabel - D. João III... cit., p. 224. COSTA, André da Silva - Os Secretários e o "Estado" do Rei: Luta de corte e poder político sécs. XVI-XVII, dissertação de Mestrado (polic.) em História apresentada à FCSH. Lisboa: 2008, p. 69-82.

${ }^{43}$ Sobretudo ANDRADA, Francisco de - Crónica de D. João III, P. III, cap. LXXXII, Introdução e revisão de ALMEIDA, Manuel Lopes de. Porto: Lello \& Irmão, 1976, p. 836. SOUSA, Fr. Luís de - Anais de D. João III, pref. e notas de LAPA, M. Rodrigues, II, P. II, cap. IX. Lisboa: Sá da Costa, 1938, p. 165-169, aduz razões de forma um pouco mais enigmática e ampla do que Andrada.

${ }^{44}$ Algumas referências sobre a questão que nos ocupa: CABEDO, António (séc. XVI), articulação absoluta com o cardinalato. V. COUTO, Aires Pereira do - O grande 'senhor' do Fontelo do século XVI, cit.. FARIA, Manuel Severim de - Noticias de Portugal, 1740, 
Poucos, como Fortunato de Almeida e Silva Dias, evidenciam como a relação entre ambos nunca foi calorosa, e que o ressentimento do monarca para com D. Miguel, que depois "explodiria" em ódio com o episódio do cardinalato, lhe era muito anterior, anterior até, segundo Silva Dias, à sua subida ao trono. Censurava o rei na figura de D. Miguel da Silva a desmedida ambição pessoal, partilhando da desaprovação que, ainda em vida de D. Manuel, a notícia da intenção de Leão X em lhe conceder a púrpura cardinalícia provocara na corte portuguesa; mas as razões seriam, acima de tudo políticas, ligadas ao papel e às iniciativas de D. Miguel no âmbito da política papal, nem sempre coincidentes com as da coroa portuguesa, no entender do rei $^{45}$.

Também Fortunato de Almeida assinala a crescente má-vontade de D. João III para com D. Miguel da Silva, indissociável do quadro de uma apertada rede de intrigas na corte, de que destaca a questão do cargo de escrivão da puridade, se bem que considere, como Herculano, que os mais sensíveis papéis e segredos de Estado eram então controlados pelos Alcáçova Carneiro. De Herculano discorda no ponto em que este, na linha interpretativa dominante, enfatiza a questão do cardinalato para explicar o ódio e a fuga de D. Miguel para Itália; Fortunato de Almeida defende, ao contrário, que a hostilidade régia para com o antigo embaixador era anterior ${ }^{46}$.

No estudo fundamental que dedica à figura de D. Miguel da Silva, Sylvie Deswarte sustenta, por seu turno, que nos quinze anos passados

pp. 264-266, referência cheia de imprecisões, situando o diferendo vagamente em torno de "alguns respeitos de estado" em que avulta o cardinalato. MACHADO, Diogo Barbosa Bibliotheca Lusitana, III, 1752, p. 483-485, em que o nexo com o cardinalato é absoluto. Entrada “D. Miguel da Silva" na Grande Enciclopédia Portuguesa e Brasileira, pp. 830-832, que acentua o ódio de D. João III e o nexo com o cardinalato. FREIRE, Anselmo Braamcamp, Brasões..., II, pp. 24-25, em que avulta o cardinalato. SANCEAU, Elaine, notas à edição de cartas da Colecção de São Lourenço, p. 205, nota 1 e p. 316, nota 2, relação exclusiva com o cardinalato. MACHADO, Rita Silvestre - D. Miguel da Silva, Dicionário Ilustrado de História de Portugal, 2, 1985, p. 230. AUBIN, Jean - La noblesse titrée..., 1996, cit., p. 380. BARBOSA, David Sampaio - Santa Sé e Portugal, Dicionário de História Religiosa de Portugal. Lisboa: Círculo de Leitores, 2000, p. 158. RAMALHO, Américo da Costa A reabilitação de D. Miguel da Silva, Boletim de Estudos Clássicos, 36, Dez ${ }^{0}$ de 2001, p. 135-136. Curiosamente, tratando-se de um muito pequeno comentário, abre-se uma "janela" interpretativa para lá do cardinalato, como acontece com Fr. Luís de Sousa.

${ }^{45}$ DIAS, José Sebastião da Silva - A Política cultural..., cit., p.96-106.

${ }^{46}$ ALMEIDA, Fortunato de - História da Igreja..., II, cit., p. 661-670. 
em Portugal, D. Miguel conseguiu manter um equilíbrio nas tensões entre o soberano e a cúria, mas nunca hesitando em apoiar o papado, em transmitir informações, em manter correspondência autónoma quer com Clemente VII quer depois com Paulo III e com a grande "máquina" política da Santa Sé, enfim, sempre pronto a trocar Lisboa pela Cidade Eterna ${ }^{47}$. Tal atitude foi sedimentando, no espírito de D. João III, uma crescente frieza e desconfiança para com o seu antigo embaixador, com episódios de inegável crispação, destacando-se a expressa proibição régia da ida de D. Miguel ao concílio ecuménico convocado por Paulo III em 1538, apesar da veemente insistência do pontífice - e do desejo do próprio. A situação de D. Miguel da Silva, no final da década de trinta, deteriorava-se rapidamente, e a sua imagem pública ligava-se, cada vez mais, aos interesses papais - e da casa Farnese $^{48}$. A 19 de Dezembro de 1539, depois de um apoio sem falhas do núncio Capodiferro, D. Miguel tomava conhecimento da sua criação como cardeal, in petto, no consistório secreto de 12 de Dezembro, o que deve ter instalado no seu espírito a ideia da fuga ${ }^{49}$.

Mas seria, de acordo com Deswarte, outra a causa imediata da ruptura. No ano de 1540, que os próprios cronistas assinalam como um momento de viragem no reinado de D. João III $^{50}$, a 21 de Abril, morreu prematuramente o cardeal-infante D. Afonso - um D. Afonso que, também por ocasião do concílio, quisera partir para Roma ${ }^{51}$ e mostrara explícita oposição à

${ }^{47}$ DESWARTE, Sylvie --Il Perfetto Cortegiano..., cit., p. 69-71.

${ }^{48}$ Em carta a Ambrogio Ricalcato (em cifra), o núncio Hieronimo Capodiferro escrevia a 25 de Novembro de 1537, sem subterfúgios: "[D. Miguel da Silva] non mostra essere Portughese, ma solo prelato nato et allevato in gembro de la Sede Apostolica, in mezo di San Pietro di Roma et particularmente servitore scorporatissimo della casa de Farnese". DE WITTE, Charles-Martial (ed.) - La Correspondance des Premiers Nonces Permanents au Portugal (1532-1553), II. Lisboa: Academia Portuguesa de História, 1980, doc. 58, p. 195 . V. ainda doc. 65 , p. 221 , doc. 87 , p. 287.

${ }^{49}$ DESWARTE, Sylvie - Il Perfetto Cortegiano...cit., p.95.

${ }^{50}$ BUESCU, Ana Isabel - D. João III..., cit., p. 251-252.

${ }^{51}$ Carta de Hieronimo Capodiferro a Ambriglio Ricalto, de 18 de Janeiro de 1538. DE WITTE, Charles-Martial (ed.) - La Correspondance ..., cit., doc. 65, p. 221. V. ainda carta de 3 de Março de 1538 do núncio ao cardeal Farnese, referindo a decisão inflexível de D. Afonso em partir para Roma, rogando a sua intercessão junto do cardeal para obter a emissão de um breve papal para o efeito, doc. 72, p. 245-246. Contudo, foi também inflexível a oposição de D. João III, a que já aludia Damião de Góis na Crónica de D. Manuel. DIAS, José Sebastião da Silva - A Política Cultural..., p. 105-106. 
eventualidade da atribuição do barrete cardinalício ao infante D. Henrique ${ }^{52}-$ ficando a abadia de Alcobaça em sede vacante. Antecipando-se a D. João III, que tinha intenção de a reivindicar para D. Henrique, D. Miguel da Silva advertiu Paulo III da situação, apressando-se o pontífice a conceder a posição ao seu neto Alessandro Farnese. Ao ser sabido, tal facto provocou indignação na família real, sendo D. Miguel da Silva e António Ribeiro acusados pelo rei de traição. Foi esta, pois, a causa imediata da ruptura, "anche se in realtà non si trattò che della goccia che fece traboccare il vaso", como afirma Sylvie Deswarte, inscrevendo este acontecimento no culminar de um processo que, precipitando-se no final dos anos trinta, era anterior ${ }^{53}$.

Há ainda a invocar, em nosso entender, uma outra situação que permite compreender melhor o ressentimento que, afinal, D. João III parece ter sempre reservado ao seu antigo embaixador. Ressentimento que não "nasceu" em 1538 com o episódio do concílio ecuménico, nem em 1539 com a concessão da púrpura cardinalícia, nem ainda em 1540 com a vacatura de Alcobaça, mas que estes episódios gravíssimos - associados a um outro até hoje nunca invocado e que adiante abordaremos - ajudaram a tornar irreversível e a mudar-se em verdadeira hostilidade. Como foi sublinhado por Silva Dias, a frieza de D. João III para com D. Miguel era antiga, fazendo-a o grande estudioso remontar ao final do reinado de D. Manuel I, em que o príncipe teria partilhado, como a generalidade da corte, da régia indignação perante a intenção papal de conceder a púrpura a D. Miguel. Pensamos poder recuar mais ainda, ao tempo do projecto de casamento do príncipe herdeiro.

São conhecidas as circunstâncias que conduziram ao terceiro casamento de D. Manuel I com D. Leonor de Áustria (n. 1498), irmã mais velha de Carlos V, em Novembro de $1518^{54}$. A morte da rainha D. Maria, em Março de 1517 , ao dar à luz o seu décimo filho, veio alterar os desígnios políticos de D. Manuel numa Península e numa Europa em pleno processo de mudança.

${ }^{52}$ Como escrevia Hieronimo Capodiferro em 13 de Abril de 1538 ao cardeal Farnese. DE WITTE, Charles-Martial (ed.) - La Correspondance...., doc. 78, p. 265-266. Em carta de 23 de Setembro, ao mesmo, aplaude a não concessão da púrpura a D. Henrique, doc. 98, p. 320 .

53 DESWARTE, Sylvie - Il Perfetto Cortegiano ..., cit., p. 93-94 e p. 213.

${ }^{54}$ BUESCU, Ana Isabel - D. João III..., cit., p. 73-101. 
Uma das mais significativas inflexões que então tomou forma prendeu-se, justamente, com o príncipe D. João. Vejamos, de forma breve, este aspecto.

No início do ano de 1516, a morte de Fernando o Católico provocou, para além de manifestações oficiais de pesar na corte portuguesa, intensas movimentações diplomáticas por parte de D. Manuel I, que não tardou em "pôr em campo" vários dos seus agentes. João Roiz de Sá de Meneses foi enviado à corte castelhana onde tratou de assuntos relacionados com a nova situação política ${ }^{55}$; a Rui Fernandes de Almada, então na Flandres, ordenou "que o avisasse de todalas cousas que pudesse alcançar, que se lá tratavam depois do falecimento del Rei D. Fernando"56; a Tomé Lopes, em carta de 8 de Fevereiro, o rei pedia notícias urgentes sobre as movimentações políticas em torno de Carlos, em particular sobre a sua eventual vinda para Castela ${ }^{57}$. Alguns dias depois, o monarca incumbia Pero Correia de encetar, junto do imperador Maximiliano, as negociações para um duplo enlace - o da infanta D. Isabel com o arquiduque de Áustria Carlos, procurando antecipar-se a outras alianças que então se gizavam, e do príncipe com D. Leonor, irmã de Carlos.

O príncipe D. João, então com catorze anos de idade, tinha já casa própria e o casamento com a infanta $\mathrm{D}$. Leonor era agora o passo que devia garantir, ainda em vida do pai e pela sua mão, a continuidade dinástica. Também na cúria papal era preciso fazer avançar a negociação, com vista a obter as necessárias dispensas. Naturalmente, foi D. Miguel da Silva quem se encarregou das diligências necessárias a esse processo, a que se referia, em cifra, na carta de 11 de Novembro de 1516 enviada a D. Manuel que referimos. A muito breve trecho, no entanto, este quadro ver-se-ia radicalmente alterado. Em Outubro de 1517 o monarca enviava Álvaro da Costa a Castela, supostamente com a principal missão de saudar o recém-chegado D. Carlos, ocasião para adiantar o acerto do casamento do príncipe com D. Leonor. Mas ao contrário do esperado, o monarca deu instruções a Álvaro da Costa para tratar e concluir, no maior segredo, não para o filho mas para si, o casamento com D. Leonor; "e foram os poderes que lhe deu

\footnotetext{
${ }^{55}$ Gavetas (As) da Torre do Tombo, vol. X, gav. XX, 6-9 e 6-10, p. 467-470.

${ }^{56}$ GÓIS, Damião de - Crónica do Felicissimo Rei D. Manuel, cit., IV, 1955, cap. 1.

${ }^{57}$ Gavetas..., cit., vol. X, gav. XX, 7-18, p. 621-622.
} 
tão largos e sem limite, que primeiro se soube em Portugal estar concluído que começado" "58. Em menos de seis meses o rei determinara, de forma inesperada, passar a "terceiras vodas" com a noiva que antes destinara ao filho, num processo que dividiu a corte e deu corpo a uma perturbadora hostilidade entre o rei e o príncipe.

Mais uma vez, quem em Roma tratou das dispensas para este controverso matrimónio, anulando todo o anterior processo, em curso, para o casamento do príncipe, foi D. Miguel da Silva, fiel executor das ordens régias. Por carta de 15 de Junho de 1518, D. Miguel informava o rei acerca da dispensa, e do seu custo, que ascenderia a 4000 réis $^{59}$. Este episódio, além de condicionar de forma irreversível a relação entre pai e filho ${ }^{60}$, deixou uma marca profunda e duradoura em D. João. Anos mais tarde, já D. João III reinava há muito, a representação da tragicomédia de Luís de Camões (1524?-80) intitulada El-Rei Seleuco (c.1543-45), que punha em cena um triângulo amoroso entre um velho rei, a sua jovem mulher e o filho apaixonado pela madrasta, evidenciava como aquele antigo episódio era ferida ainda não sarada. Segundo alguns críticos, quer D. João III quer D. Catarina ter-se-iam melindrado com as alusões do auto, acarretando o desfavor de Camões na corte e o seu desterro para o Ribatejo ${ }^{61}$.

Assim, embora sem uma "prova" positiva, não custa a crer que a figura de D. Miguel da Silva, destacado agente das vontades do seu pai e seu fiel executor, mas que nessa condição acabou por interferir no seu destino, conhecedor, como poucos, dos segredos da coroa portuguesa junto da Cúria romana, o que fazia dele um homem por dentro do poder, íntimo e particular amigo de papas e de cardeais, não fosse simpática a D. João III, antes mesmo do seu regresso ao reino, antes ainda da própria ascensão do "Piedoso" ao trono, como pensamos.

Depois, quando de forma relutante regressou a Portugal, é certo que D. Miguel da Silva se viu cumulado de honrarias, distinções e mercês por um rei cujos desígnios permanecem fundamentalmente ambíguos, talvez

${ }^{58}$ SOUSA, Frei Luís de - Anais de D. João III, cit., liv. 1, cap. 4, p. 23.

${ }^{59}$ ANTT, CC, P. I, mç. 23, doc. 62.

${ }^{60}$ ANDRADA, Francisco de - Crónica ..., cit., I, cap. 6.

${ }^{61}$ CAMÕES, Luís de - Teatro (Anfitriões, El-Rei Seleuco e Filodemo), CARDOSO, José e SÁ, Domingos Guimarães de (org.), Braga: Câmara Municipal, 1980, p. 25-26 e 123-169. 
"[...] com a esperança de o atrair, ou com desejo de o anular", como já foi finamente observado ${ }^{62}$. Mas estas honrarias e benesses não só suscitaram mal-estar na corte como a sua atribuição se deveu, em grande medida, a pressões do papa Clemente VII, que enviou um breve a D. João III, pela mão do próprio D. Miguel da Silva, recomendando-lhe muito o seu grande amigo português ${ }^{63}$. Foi este o caso do bispado de Viseu, que D. Miguel da Silva recebeu por intercessão papal, porventura sem grande empenhamento do próprio D. João III. A terminante recusa do papa Adriano VI em prover D. Henrique no lugar de bispo de Viseu em 1522 não podia deixar de estar bem presente no espírito do monarca, agora que Clemente VII pedia aquele lugar episcopal para D. Miguel da Silva. Aliás, a própria demora entre a nomeação papal, por bula de 21 de Novembro de $1526^{64}$ e a sua sagração como bispo, ocorrida em 1529, dá conta das resistências havidas na obtenção da dignidade de bispo de Viseu ${ }^{65}$, que D. João III continuaria a pretender para o irmão, após prover no lugar o já idoso Fr. João das Chaves em $1524^{66}$.

Tal situação não impediu D. Miguel da Silva de tomar conta do governo da diocese como bispo eleito, fazendo publicar, em Outubro de 1527, as Constituições do Bispado de Viseu. O frontispício da edição ostenta

${ }^{62}$ DIAS, José Sebastião da Silva - A Politica Cultural..., cit., p.79.

${ }^{63}$ CDP, II, pp. 253 ss.

${ }^{64}$ Embora já em 23 de Março o papa manifestasse ao rei a sua satisfação pela escolha (CDP, II p. 264). Em 8 de Janeiro desse ano de 1526, D. Miguel da Silva escrevia uma carta ao cabido de Viseu, solicitando informação sobre as necessidades da igreja, para delas poder dar seguimento enquanto não chegavam as bulas papais de confirmação. Catálogo do Arquivo do Museu de Grão Vasco [I] [em CD-ROM] SARAIVA, Anísio Miguel de Sousa (coord.), Viseu: Instituto dos Museus e da Conservação, Museu Grão Vasco, 2007, AMGV/ /DA/COR/027. Nova carta ao cabido da Sé, de 7 de Julho, Catálogo..., cit., AMGV/DA/ /COR/030.

${ }^{65}$ ALMEIDA, Fortunato de - História da Igreja..., cit., II, p. 663, nota 2. Em carta de 4 de Fevereiro de 1527, já D. Miguel anunciava ao cabido da Sé a sua próxima tomada de posse através do seu procurador João Mendes, que seria portador de uma provisão apostólica, o que não veio a acontecer. Catálogo ...cit., AMGV/DA/COR/34.

${ }^{66}$ PAIVA, José Pedro - Os Bispos... cit., p. 304-305. O franciscano, provido a 9 de Setembro de 1524 como bispo de Viseu era, ainda em Abril de 1525, bispo daquela diocese, e continuava a desempenhar junto de D. João III o cargo de "padre espirituall e mestre de pulpeto". Carta do Bispo do Algarve ao Bispo de Viseu, de 30 de Abril de 1525, Colecção de São Lourenço, I, Pref. e Notas de SANCEAU, Elaine, Lisboa: CEHU, 1973, p. 331. Erradamente se diz em nota que se tratava de D. Miguel da Silva. Fr. João das Chaves morreu em finais de 1525 ou princípios de 1526. ALMEIDA, Fortunato de - História da Igreja... cit., p. 661 . 
as dignidades de bispo de Viseu, do conselho do rei e seu escrivão da puridade; mas esse mesmo ano de 1527 - o ano do saque de Roma e do aprisionamento de Clemente VII em Sant'Angelo por ordem de Carlos V assinalava também o início da correspondência entre o papa e D. Miguel da Silva, com um só sentido: o do regresso do agora bispo de Viseu à amada Roma $^{67}$. Nos anos que permaneceu em Portugal, a sua importante e coerente acção mecenática e artística foi também em certo sentido, para lá de outras considerações, um acto de nostalgia.

Durante a sua estadia no reino, D. Miguel da Silva, intelectualmente formado num contexto cultural marcado pela paixão filológica de recuperação dos modelos antigos, pelo neo-platonismo florentino e pelo ambiente de uma Roma que era então, com a construção de S. Pedro, um "cadinho" de formação dos arquitectos sob o poderoso influxo da Antiguidade Clássica mostrou-se, verdadeiramente, um "prelado à italiana"68. Com as suas estátuas, bustos e manuscritos, D. Miguel da Silva trouxe também projectos de construção nas suas terras, procurando nelas "reproduzir o ambiente romano", com destaque para o programa concebido, enquanto abade comendatário do mosteiro de Santo Tirso, para a Foz do Douro. A igreja de S. João da Foz perfila-se como um "verdadeiro manifesto da arquitectura renascentista" ${ }^{69}$, no quadro de um programa arquitectónico complexo que incluiu a fortaleza de S. João Baptista e a capela de S. Miguel-o-Anjo, de 1528 - "a primeira obra em Portugal de onde o gótico foi totalmente banido!'70. Tratava-se, num país em que predominavam cânones artísticos arcaizantes, de verdadeira obra de vanguarda, que contou com o contributo do arquitecto Francesco de Cremona, que trabalhara em S. Pedro com Bramante e Rafael, cuja vinda de Itália foi patrocinada por D. Miguel da Silva, talvez logo em 1525, acompanhando o ex-embaixador no seu regresso ao reino ${ }^{71}$. O seu intuito seria o de dotar a foz do Douro de um grande porto de mar que proporcionasse à cidade do Porto um contacto mais intenso e

${ }^{67}$ CASTRO, José de - Dom Miguel da Silva: o 'Cardeal de Viseu', cit., p. 2.

${ }^{68}$ Expressão de DESWARTE, Sylvie - Il Perfetto Cortegiano..., cit., p. 66.

${ }^{69}$ DESWARTE, Sylvie - Il Perfetto Cortegiano ..., cit., p.67.

${ }^{70}$ MOREIRA, Rafael - D. Miguel da Silva e as origens da arquitectura... cit., p. 14.

${ }^{71}$ Cremona trabalhou para D. Miguel da Silva como seu arquitecto privado, caso único em Portugal e raro na Europa do tempo, como foi sublinhado por Rafael Moreira. 
directo com a Europa, e um conjunto monumental que rivalizasse com o dos Jerónimos à entrada de Lisboa ${ }^{72}$.

Também em Viseu D. Miguel da Silva teve uma acção cultural notável, impulsionando o enraizamento dos novos ideais estéticos quer sob o ponto de vista arquitectónico, em particular na catedral, com a construção do claustro (c. 1528-34) por Cremona, a varanda, o coro alto e o cadeiral, quer procedendo a encomendas à oficina de Vasco Fernandes, que assim beneficiou deste impulso renovador de acordo com os ideais renascentistas. Também a quinta episcopal do Fontelo, pensada por D. Miguel como uma villa à italiana rodeada de jardins, lagos e grandes gaiolas de pássaros, encontrou renovado esplendor ${ }^{73}$; o próprio D. Miguel se empenhava na descoberta de testemunhos dos Antigos através do interesse pela exumação arqueológica. Em 1537 envolvia-se - com razão - em polémica com o antiquário André de Resende, a propósito da inauguração do aqueduto de Évora, e em 1538 enviava ao cardeal Farnese uma colecção de medalhas antigas $^{74}$. E foi sob a sua égide que Sá de Miranda e Bernardim Ribeiro demandaram, entre 1521 e 1526, terras de Itália e Francisco de Holanda fez a sua decisiva estadia italiana ${ }^{75}$. Em suma, como sintetiza Rafael Moreira, que de forma pioneira lançou luz sobre o papel do bispo de Viseu na eclosão das formas culturais renascentistas em Portugal, D. Miguel da Silva "foi um verdadeiro mecenas, à altura dos cardeais Amboise e Mendoza em França e Espanha, patrono esclarecido e generoso que colocou a sua fortuna [...] ao serviço da renovação das artes no sentido renascentista, em pleno apogeu do gosto manuelino" 76 .

${ }^{72}$ MOREIRA, Rafael - D. Miguel da Silva e as origens da arquitectura... p. 12.

${ }^{73}$ MOREIRA, Rafael - D. Miguel da Silva e as origens da arquitectura... cit., p. 18-23. DESWARTE, Sylvie - Il Perfetto Cortegiano..., cit., p. 12-68. COUTO, Aires Pereira do O grande 'senhor' do Fontelo do século XVI: D. Miguel da Silva, cit.. RODRIGUES, Dalila - Vasco Fernandes, ou a contemporaneidade do diverso, Grão Vasco e a Pintura Europeia do Renascimento. Catálogo da Exposição (17 de Março a 10 de Junho de 1992) Lisboa: CNCDP, 1992, p. 29-75.

${ }^{74}$ Carta de Hieronimo Capodiferro ao cardeal Alessandro Farnese, de 18 de Janeiro de 1538, DE WITTE, Charles-Martial (ed.), La Correspondance ..., cit., doc. 66, p. 225.

${ }^{75}$ DESWARTE, Sylvie, seguindo a tese de Guido BATELLI, sustenta a ligação de D. Miguel da Silva a Francisco de Holanda e o impulso que terá dado à estadia italiana do artista, a que o próprio não podia referir-se em virtude da queda em desgraça de D. Miguel da Silva na corte portuguesa. DESWARTE, Sylvie - Il Perfetto Cortegiano..., cit., p. 176, nota 8.

${ }^{76}$ MOREIRA, Rafael - D. Miguel da Silva e as origens da arquitectura..., cit., p. 9. 
Não esmoreceu, contudo, o seu desejo de voltar a Roma. Em 1532, D. Miguel escrevia ao papa Clemente VII em termos que não deixam quaisquer dúvidas ${ }^{77}$. Esse firme desiderato manteve-se depois da morte, ocorrida em Setembro de 1534, de Clemente VII, de quem D. Miguel era amigo dilecto. O contexto favorável a $\mathrm{D}$. Miguel da Silva em Roma não mudava, pois quem agora subia ao sólio pontifício, tomando o nome de Paulo III, era o cardeal Alessandro Farnese, de cujo neto homónimo (n. 1520) D. Miguel da Silva era padrinho de baptismo. O que ia mudando era a sua situação no reino, que afinal o acolhera friamente e no qual, verdadeiramente, D. Miguel nunca se reintegrara ${ }^{78}$.

No final dos anos trinta, a ruptura entre D. João III e o bispo de Viseu, alicerçada nos graves episódios ocorridos em 1538-40 tornou-se inevitável, num quadro que deve também ser visto no âmbito mais vasto das relações da coroa portuguesa e da Santa Sé. Na verdade, esta crise é também demonstrativa da intervenção da coroa na hierarquia eclesiástica ao mais alto nível, procurando D. João III consolidar a política manuelina de reservar a dignidade de cardeal para os membros da família real, neste caso os irmãos ${ }^{79}$. Neste sentido, o pouco invocado insucesso na atribuição da púrpura a D. Henrique em $1538^{80}$ e a concessão da dignidade de príncipe da Igreja

77 DE WITTE, Charles-Martial (ed.) - La Correspondance ..., II, 1980, doc. 2, p. 9-10.

${ }^{78}$ Em carta de 15 de Julho de 1531 a António de Ataíde, o mais chegado amigo e valido de D. João III, que o monarca faria conde da Castanheira em 1532, então em França em missão diplomática, dizia D. Miguel da Silva, estando com a corte em Évora: "Senhor esta terra é tão calmosa e tam Guineé em tudo que não quero deixar de lembrar Vossa Merce que nam se trabalhe muito ha vinda porque he mui diferente cousa yr destes ares para esses e vir desses pera estes". Em nossa opinião, esta apreciação climática de D. Miguel da Silva é subliminarmente metafórica. Colecção de S. Lourenço I, cit., p 207. Em carta dirigida a Clemente VII, D. Miguel falava dessa estreiteza de horizontes do reino, a que nunca se adaptara: "[...] io qua si lontano et in paesi dove le occasioni illustri in che l'huomo si poteria mostrare arrivano come le navi d'India doppo due anni che sonno partiti [...]". DE WITTE, Charles-Martial (ed) - La Correspondance..., cit, doc. 2, p. 9.

${ }^{79}$ BETHENCOURT, Francisco - A Igreja, in História de Portugal, dir. MATTOSO, José., 3 - No Alvorecer da Modernidade (1480-1620), MAGALHÃES, Joaquim Romero (coord.) Lisboa: Círculo de Leitores, 1993, p. 156-157. PAIVA, José Pedro - Os Bispos..., cit., p. 38-53, p. 298.

${ }^{80}$ A que se opusera o cardeal D. Afonso, evidenciando uma fractura de importantíssimo alcance na família real, e fora aplaudida pelo núncio Capodiferro. V. supra, nota 53. 
a D. Miguel da Silva em $1539^{81}$, num quadro de já antiga frieza por parte do rei, não podia ter sido recebido pelo monarca senão como uma afronta. Sem subterfúgios, a 29 de Abril de 1539, poucos meses antes da fuga, em carta ao cardeal Farnese, D. Miguel da Silva afirmava que escreveria doravante mais raramente, por causa dos seus muitos inimigos, pedindo ao cardeal que queimasse as suas cartas ${ }^{82}$.

O perfil dos protagonistas, o eco e a importância política deste episódio ajudam a explicar que a historiografia tenha em geral considerado a concessão do cardinalato como a causa directa, imediata e exclusiva da ruptura entre D. João III e D. Miguel da Silva, da fuga deste para Itália e da perseguição tenaz e duradoura que lhe moveu o rei ${ }^{83}$. Na verdade, em nosso entender, estamos perante um conjunto complexo de razões em que o cardinalato é uma, mas não a única das razões da reserva e da hostilidade de D. João III, que chegou a volver-se em verdadeira inimizade e ódio, envolto também numa sombria campanha de insinuações e de calúnias de natureza pessoal ${ }^{84}$. Falámos já do quadro que conduziu ao terceiro casamento de D. Manuel em 1518, do mal-estar na corte portuguesa perante a hipótese de concessão do cardinalato em 1521, e do contexto de final dos anos trinta, com os episódios do concílio ecuménico, do cardinalato para D. Henrique e da vacatura de Alcobaça; mas será necessário também invocar a oposição de D. Miguel da Silva, a partir de certo momento notória, ao estabelecimento da Inquisição no reino - posição na qual, aliás, era acompanhado por outras destacadas figuras

${ }^{81}$ Que também fora devidamente "trabalhada" em Portugal pelo próprio bispo de Viseu. Em carta cifrada do então núncio papal junto da corte portuguesa ao cardeal Farnese, datada de 16 de Setembro de 1538, Hieronimo Capodiferro propunha D. Miguel da Silva para o cardinalato, sublinhando os seus méritos e riquezas, e recomendando o uso estrito do segredo em tão sensível matéria. DE WITTE, Charles-Martial (ed.) - La Correspondance ..., doc. 97, p. 313-315.

${ }^{82}$ DE WITTE (ed.) - La Correspondance..., doc. 119, p. 366-367.

${ }^{83}$ Sobre a fuga de D. Miguel, ANTT, Colecç̧ão de S. Vicente, 1, fols. 111-184.

${ }^{84}$ Com acusações de pederastia e homossexualidade, partilhadas pelo próprio rei, de acordo com o que o núncio Ricci escrevia ao cardeal Farnese, a 12 de Julho de 1548. DE WITTE (ed.) - La Correspondance..., cit., doc. 259, p. 603. O nome de D. Miguel da Silva surge nas famosas pasquinate, versos satíricos anónimos afixados em Roma por volta do dia 25 de Abril de cada ano e por ocasião dos conclaves. DESWARTE, Sylvie - Il Perfetto Cortegiano..., cit., p. 113-114 e carta de Luis Sarmiento a Carlos V, de 30 de Julho de 1540, doc. 18, p. 154. Também Herculano alude, embora de forma vaga, a esta questão. História da Origem ..., cit., p. 269. 
próximas de D. João III, como António de Ataíde, o conde de Vimioso, e o secretário António Carneiro ${ }^{85}$ - ligando-se aos cristãos-novos, de quem se tornou defensor na cúria romana ${ }^{86}$.

Mas nenhuma delas, nem todas no seu conjunto nos pareceu, sempre que nos debruçámos sobre este perturbador episódio, matéria suficiente para explicar a desmesura do ódio - de um ódio que nunca se extinguiu - que D. João III, por natureza ressentido e dissimulado mas controlado e verdadeiramente prudente, concebeu por D. Miguel da Silva ao ponto de, além de o ter desnaturalizado no início de $1542^{87}$, despojando-o de rendas e quaisquer privilégios, mercês e imunidades, fazendo-o renunciar ao bispado de Viseu ${ }^{88}$ ter, comprovadamente, ordenado o seu assassínio ${ }^{89}$, sujeitando ainda a família à proibição absoluta de contacto com D. Miguel e a vexames intoleráveis, se tivermos em consideração o seu estatuto social e a proximidade com o rei ${ }^{90}$. Essa estranheza perante a violência régia é comum a vários estudiosos, que assinalam esse facto sem o explicarem, como é o caso de José de Castro. Também para ele a questão do cardinalato sobreleva todas as outras; contudo, é talvez também o autor onde é mais visível a perplexidade perante a veemência do ódio de D. João III: “[em] 1543, era já um ódio com cinco anos de idade, portanto um ódio anormal,

${ }^{85}$ BUESCU, Ana Isabel - D. João III..., cit., p. 233.

${ }^{86}$ Como sintetiza Herculano, que se ocupa da questão, "Hostilizar a Inquisição era ferir el-Rei numa das suas mais caras afeições". HERCULANO, Alexandre - História da Origem ..., cit., II, p. 296. MOREIRA, Rafael - Miguel da Silva e as origens da arquitectura..., cit., p. 8-9. V. ainda, a propósito, a carta do embaixador Luis Sarmiento a Carlos V, de 30 de Julho de 1540, publ. por DESWARTE, Sylvie - Il Perfetto Cortegiano..., cit, doc. 18, p. 154 .

${ }^{87}$ Após D. Miguel ter recebido do papa Paulo III o barrete cardinalício em 2 de Dezembro de 1541. Nesse mesmo dia, António Ribeiro, da comitiva do bispo, escrevia ao conde de Portalegre, irmão de D. Miguel, sublinhando que à comum alegria, só faltava o contentamento do rei (CDP, IV, p. 384 ss). No dia 5, em Veneza, o próprio D. Miguel da Silva escreveu ao rei, manifestando-lhe lealdade ( $C D P$, IV, p 395ss). A 10 do mesmo mês, D. Miguel comunicava a sua elevação a cardeal à diocese de Viseu. Catálogo ..., cit., AMGV/DA/COR/078.

${ }^{88} \mathrm{~V}$. a carta régia de 23 de Janeiro de 1542, publicada por ANDRADA, Francisco de Crónica...., P. III, cap. 82, ed. cit., p. 836-837.

${ }^{89}$ HERCULANO, Alexandre - História da Origem ..., cit., p. 273-276. ALMEIDA, Fortunato de - História da Igreja ... cit., p. 664 e nota 4.

${ }^{90}$ D. João da Silva (†1550?51?), $2^{\circ}$ conde de Portalegre, irmão mais velho de D. Miguel, exercia o cargo de mordomo-mor de D. João III desde 1522. FREIRE, Anselmo Braamcamp - Brasões... III, cit., p. 367. 
ou talvez fosse um ódio de natureza diplomática. Só por um grande interesse de ordem política e diplomática é que se pode explicar este ódio que parece diferente de todos os ódios, pois em vez de emagrecer com o tempo, ganha com o tempo maior estatura" $"$.

Existe, pois, uma outra razão ${ }^{92}$ que traz, em nosso entender, a uma nova luz a desmesura do ódio de D. João III por D. Miguel da Silva, um ódio "diferente de todos os ódios", que em vez de se atenuar com a passagem do tempo, com o tempo ganhava maior estatura, como escreve José de Castro. Precisamente o que dizia o núncio papal junto da corte portuguesa, Giovanni Ricci, ao cardeal Farnese, em 12 de Junho de 1548, oito longos anos após a fuga de D. Miguel: “[...] l'odio del re verso il cardinale de Silva è più caldo hoggi che fusse mai" ${ }^{93}$. E na verdade, embora sem o conseguir situar em concreto, tinha razão aquele estudioso ao intuir que a actuação de D. João III, se bem que precipitada pelos graves acontecimentos referidos, só podia explicar-se ligando-se a uma poderosíssima razão de ordem política e diplomática, que superava, mesmo, a questão do cardinalato. Razão hoje quase desconhecida e nunca invocada, mas da qual sabemos que o monarca teve conhecimento: a insinuação da insuficiência da dispensa do casamento de D. Manuel com a rainha D. Maria, que D. Miguel da Silva, conhecedor dos segredos de Estado em virtude da sua dupla condição de embaixador junto da Cúria papal e de escrivão da puridade a partir de 1525, fez constar junto do papa e do próprio imperador Carlos V.

Da questão da insuficiência das dispensas do casamento de D. Manuel com D. Maria e do uso político que dela fez D. Miguel da Silva temos conhecimento indirecto, mas absolutamente inquestionável, sendo certo que ulteriores investigações, em concreto nos arquivos papais, poderão vir a iluminá-la de forma mais ampla e pormenorizada. É no contexto

${ }^{91}$ CASTRO, José de - Dom Miguel da Silva: o 'Cardeal de Viseu', cit., p. 3. Sublinhados nossos. Também Arlindo Correia explicita, de forma sucinta mas não menos expressiva, essa estranheza: "Torna-se difícil explicar o ódio de D. João III contra D. Miguel da Silva, tanto mais que não surgiram grandes dificuldades para nomear Cardeal o Infante D. Henrique". CORREIA, Arlindo - D. Miguel da Silva, o 'Cardeal Viseu' (http://www.arlindo-correia. com/140606.html, consultado em 20.2.2008)

${ }_{92}$ BUESCU, Ana Isabel - D. João III..., cit., p. 231.

${ }^{93}$ Carta de Giovanni Ricci a Alessandro Farnese, de 12 de Junho de 1548, DE WITTE, Charles-Martial (ed.) - La Correspondance ..., cit., doc. 259, p. 603. 
da sucessão do reino de Portugal após a morte de D. João III, em 1557, quando estavam já em marcha uma série de diligências secretas, por parte de Carlos V, envolvendo a sua irmã D. Catarina e Francisco de Borja, para assegurar o juramento do infante D. Carlos (n. 1545) ${ }^{94}$ como legítimo herdeiro do trono português na eventual falta de D. Sebastião (n. 1554) ${ }^{95}$, consumando assim o velho sonho da união ibérica, que encontramos prova irrefragável da transmissão do secretíssimo assunto a Carlos V pela mão de D. Miguel da Silva.

Em carta cifrada de Carlos V a seu filho Filipe II, de 31 de Março de 1558, pouco antes de morrer, decorrendo aquelas manobras relativas à sucessão do reino de Portugal, o imperador invocava a conversa que, muitos anos antes, mantivera com "el cardenal de Viseo", a propósito desta delicada e melindrosa matéria. Nesse encontro falara-lhe D. Miguel da Silva na “dispensación del rey don Manuel con la reyna doña Maria [...] poniendo duda de no ser bastante, y el impedimiento que por esta causa hauia". "Lo qual siendo assí - concluía Carlos V - el rey don Joan y sus hermanos $y$ los demás no podrían pretender el Reyno" ".96. Conclusão devastadora que, do nosso ponto de vista, traz a uma nova luz a desmesura do ódio de D. João III por D. Miguel da Silva, que os historiadores assinalam sem verdadeiramente explicar: o que estava em causa, na escaldante informação que D. Miguel fizera saber ao imperador era o da própria ilegitimidade dos reis de Portugal que agora, após a morte de D. João III e a sua sucessão pelo rei-criança D. Sebastião, tomava, na óptica do velho e cerebral imperador, a dimensão de potencial arma política.

A uma nova luz deve também ser vista uma outra questão, que atravessou todo o reinado de D. João III, e que nesta conjuntura ganhava uma nova e premente acuidade: a da partida da infanta D. Maria (n. 1520), já não para junto da mãe D. Leonor de Áustria, como esta sempre reclamara,

${ }^{94}$ Filho do então Filipe das Astúrias (n. 1527), e da princesa D. Maria (n. 1527), filha de D. João III e de D. Catarina, que morreu ao dá-lo à luz.

${ }^{95}$ Sobre este assunto, BUESCU, Ana Isabel - Catarina de Áustria (1507-1578). Infanta de Tordesilhas, Rainha de Portugal. Lisboa: A Esfera dos Livros, 2007, p. 320-324 e p. 332-334.

${ }^{96}$ Corpus Documental de Carlos V, IV (1554-1558). Apendice. Las Memorias del Emperador, Edición crítica, prologada y anotada por FERNÁNDEZ ÁLVAREZ, Madrid: Espasa Calpe, 2003, doc. DCCXCIX, p. 411-415. 
sem sucesso, junto de D. João III ${ }^{97}$, pois a rainha de França falecera em Fevereiro de 1558, mas para fora do reino de Portugal onde, a ser certa a ilegitimidade dos descendentes do matrimónio D. Manuel com D. Maria, a infanta poderia, se o cenário se proporcionasse, aspirar à condição de rainha. Há, aliás, indícios de que esta ideia andou um pouco "no ar" em Portugal, em certos círculos da corte, quando a questão da dispensa se tornou pública, e que essa situação, num contexto político difícil como foi o do início da regência de D. Catarina ${ }^{98}$, terá, por momentos, feito acalentar expectativas à própria infanta, como aliás é explícito da referência de Carlos $\mathrm{V}^{99}$. De tudo isto, e nestes termos, falava o imperador na sua carta a Filipe II, que era, ao mesmo tempo, um relato da delicadíssima missão de Francisco de Borja em Portugal, nomeadamente junto de D. Catarina ${ }^{100}$.

Era D. Miguel da Silva, verdadeiramente, um homem por dentro do poder, e nessa medida, uma figura temível, do ponto de vista político - o que veio, portanto, a acontecer. Enquanto embaixador em Roma tratara dos negócios mais sensíveis e secretos da coroa portuguesa. A sua condição de embaixador fizera-o conhecedor - e possuidor - desses segredos e desses e de outros negócios da coroa portuguesa, e a sua nomeação como escrivão da puridade de D. João III, por muito que António Carneiro e o próprio rei quisessem reservar assuntos e que, até, o cargo já não correspondesse à importância efectiva que tivera noutros tempos, com a ascensão da figura do secretário, vinha nessa continuidade ${ }^{101}$. Aliás, a carta régia de desnaturalização de

${ }^{97}$ BUESCU, Ana Isabel - D. João III... cit., p. 173-176.

${ }_{98}$ BUESCU, Ana Isabel - Catarina de Áustria ... cit., p. 327-348.

${ }^{99}$ Como aconteceria mais tarde, no final da regência de D. Catarina e a sua transmissão ao cardeal D. Henrique, em que o nome da infanta voltou a ser ventilado. CRUZ, Maria do Rosário Themudo Barata de Azevedo - As Regências na Menoridade de D. Sebastião. Elementos para uma história estrutural, I. Lisboa: IN-CM, 1992, p. 273-275.

100 “[...] visto después de la muerte del Rey [D. João III] que lo que yo pensé que era muy secreto que hauia dicho el dicho Cardenal [de Viseu] es tan publico en Portugal y que esto hauia hecho leuantar los pies a la Infanta [D. Maria], para persuadirse a creer algunas cosas que no debría, me paresçio que era más conueniente su venida por quitar estos embaraços". Carta de Carlos V a Filipe II, Corpus Documental..., cit., p. 413. Sublinhados nossos.

101 "Puridade - segredo intimo de alguma pessoa, principalmente real". VITERBO, Joaquim de Santa Rosa de - Elucidário das Palavras, Termos e Frases que em Portugal Antigamente se usaram..., edição crítica, II, Porto-Lisboa: Civilização, 1966, p. 501. BUESCU, Ana Isabel - D. João III, cit., p. 223-224. COSTA, André da Silva - Os Secretários e o "Estado" do Rei..., cit. 
D. Miguel da Silva, publicada em 23 de Janeiro de 1542, era eloquente, enfatizando o acesso de D. Miguel aos mais graves e secretos assuntos de Estado $^{102}$. Em particular, todos os processos matrimoniais ocorridos durante a sua permanência na Cúria - do então príncipe D. João com D. Leonor de Áustria, que não se realizou, de D. Manuel com a mesma em 1518 e de D. João III com D. Catarina de Áustria, em 1524 - e a obtenção das dispensas necessárias correram pela sua mão. Questões sempre sensíveis, como já acontecera no passado e ficaria bem claro, pouco depois do seu regresso, por ocasião do casamento da infanta D. Isabel com o imperador Carlos V, concebido por D. Manuel e uma das mais expressivas vitórias diplomáticas dos primeiros anos de reinado de D. João III. Na verdade, depois da assinatura do contrato nupcial, a 17 de Outubro, houve dois recebimentos solenes, o primeiro a 1 de Novembro de 1525, o segundo a 20 de Janeiro de 1526, porque foi necessária nova dispensa de Clemente VII, mais ampla, já que a primeira fora considerada insuficiente, em virtude do estreitíssimo parentesco entre os nubentes ${ }^{103}$.

Regressando ao crucial período que se seguiu à morte de D. João III, o rumo dos acontecimentos encarregou-se de esfumar todas estas considerações, todas estas ponderações, todos estes cenários: nunca o príncipe D. Carlos, de infeliz destino, alguma vez foi jurado herdeiro do reino de Portugal, nem sobre a dinastia de Avis, nas pessoas de D. João III ou de D. Sebastião recaiu o labéu da ilegitimidade, nem para a infanta D. Maria, a Sempre Noiva, alguma vez se veio a perfilar o trono. À distância de cinco séculos, tudo isto pode parecer, numa leitura mais rápida ou orientada apenas pelo que na realidade aconteceu, um pouco irrelevante e inconsequente. Ao contrário, estas foram questões que estiveram no âmago do acontecer político, no que ele tem de volitivo, mas também de aleatório e de incerto, e nos destinos dos reinos de Portugal e de Espanha no século de Quinhentos.

E voltando ao tema central que aqui nos ocupou, que foi o de procurar entender de forma mais nítida os contornos e a evolução do dissídio entre D. João III e D. Miguel da Silva, pensamos poder afirmar, à luz dos argumentos expendidos, que estamos, de facto, perante novas razões para um ódio velho.

\footnotetext{
${ }^{102}$ Publicada por ANDRADA, Francisco de - Crónica...., P. III, cap. 82, ed. cit., p. 836.

${ }^{103}$ BUESCU, Ana Isabel - D. João III... cit., p. 188-191.
} 